\title{
DIAGNOSTIC OF SOIL SUITABILITY FOR HOUSING AND ROAD CONSTRUCTION: A CASE STUDY OF SUBURBAN TOWNS AROUND LUCKNOW CITY OF UTTAR PRADESH, INDIA
}

\author{
Ajai Kumar Rai ${ }^{1}$, Brajesh Mishra ${ }^{2}$ \\ ${ }^{I}$ Assistant Professor, Department of Civil Engineering, Sri Ram Swaroop Memorial College of Engineering \& \\ Management, Lucknow, Uttar Pradesh, India \\ ${ }^{2}$ Assistant Engineer, U.P. Cane Development Department, Lucknow, Uttar Pradesh, India
}

\begin{abstract}
Settlements of buildings in a particular area is common. These settlements poses a threat to safety and well being of the residents of that particular area. Development of cracks or ultimate failure i.e collapse of the structures may result due to unsuitable /unstable soils on which these structures are constructed. From engineering point of view soil is considered in terms of its suitability as building materials or as support medium for roads, buildings and other structures. Soil characteristics assessment is essential for the stability of the building constructed at particular placelarea. It's not only provides the constructors to select a better locality for the development of buildings or roads to minimise the losses due to settlement but also reduces the cost of construction. A comparative study was conducted among seven towns around Lucknow city ranging from 4 to $15 \mathrm{~km}$ from the existing boundary. The present developments of the Lucknow city indicates that the selected towns will be the part of the Lucknow city in near future. The samples were collected for each selected town site were used for investigation. The soil samples collected were subjected to specific gravity, natural moisture content, particle size analysis, consistency limits, void ratio, porosity, compaction, permeability and direct shear tests.The statistical analysis was used to obtain the mean values of the result obtained from each variable. Soil and site rating score was designed using the evaluation key to determine the suitability of the soil for housing and road construction for each area.
\end{abstract}

Keywords: Settlement, Particle Size Analysis, Specific Gravity, Natural Moisture Content, Consistency Limits, Direct Shear Test.

\section{INTRODUCTION}

Upgradation of a town into city involves the construction of almost all type of civil engineering structures e.g. residential \& commercial buildings, roads, overhead tanks, civil works related to sanitary and water supply etc. If the settlement is uniform or within the limit the structure/civil works constructed over it is safe while if differential settlement takes place it results in either the development of cracks or the failure of the structures. Soil characteristics of the ground/land is primarily responsible for the differential settlement. An assessment of soil properties around Lucknow city was carried out on all roads outgoing the city where the possible growth or extension of the city is inevitable. This ensures not only the safety of the structure as well as people but also the constructors to select a better locality for the development. Further it enables reducing the construction cost and helps to determine the corrective measures to improve the ground condition thus reducing the settlements within the permissible limit.Thus the settlement problems which is likely to occur in future may be avoided.The inherent soil properties which are natural ability of the soil to function and are permanent and do not change easily. These properties of the soil are used to compare the ability of one soil against another and to assess the suitability of soils for specific purposes. The physical attributes of the soil which may be used as indicators of soil qualities are soil texture, stoniness, soil structure, bulk density, porosity, soil crusting, compaction, drainage, water retention, infiltration, hydraulic conductivity and topsoil depth. The considerations of the properties depend upon the use/purpose for the construction of embankments for highways and railways shear strength is the main property to be considered. Physical properties particle size gradation, void ratio, atterberg's limit, density, strength, compressibility, permeability etc are of main concern if the soil is used as a foundation material. Lucknow is the capital city of most populous state named Uttar Pradesh in India covering an area of appox. 2400-2700 sq. Km. situated in stretch ranging from $80^{0} 30$ 'to $81^{0} 13$ ' East longitude and 26 $030^{\prime}$ to $27^{\circ} 10^{\prime}$ North latitude. It is surrounded by Barabanki district on the east, Sitapur \& Hardoi district on north, Unnao on the west and Raebareli in the south. Road and railway connectivity from the prominent places of india exist and evidence of proper functioning of communicational network. It is connected by Delhi, Bhopal ,Bihar (Mokama) and Varanasi through NH 24,25,28 and 56 respectively and Hardoi, Raebareli, Sultanpur and Mohaan through State highway 25,36,56 and40 respectively. Intercity connectivity is achieved through numerous bridges on Gomti river, which divides the city in almost two halves i.e. Hardinge/Pakka/Lal bridge,Iron bridge, University Bridge, Nishatganj bridge in old Lucknow and Gomti 
barrage, Gandhi setu and Ambedkar bridge in new Lucknow. Recent development in the field of intercity communication is $23 \mathrm{~km}$ long elevated Amar Shahid Path starting from Faizabad road passing through Sultanpur road and Raibareli road and ends at Kanpur road. With the facility of Metro rail project under progress covering the whole city this city is presently in the rapid development stage. The main aim of this paper is to identify the area of foundation suitability keeping in view the radial expansion of city along the outgoing roads of the city so that economic planning for future expansion of city may be achieved and the settlements of the buildings which is likely to occur in future may be avoided or corrective measures at the construction stage can be executed for the stability of the civil structures constructed on these.

\section{METHODOLOGY}

\subsection{Measured Soil Properties}

The safety and strength of a building depends to a large extent on soil properties. Even a great construction plan may have certain limitations depending on the kind of soil may lead to either to an added expense or the tumbling of the structure, which ultimately shows the failure of the plan. Hence it is the requisite of construction is the awareness of the soil characteristics For the purpose of measuring the soil properties of the selected towns the properties based on the particle size analysis, consistency limits, shear strength and compressive strength and properties relating to flow through soils were determined of all the selected sites as shown in table1.

Table-1 Measured Soil Properties of Selected Sites

\begin{tabular}{|c|c|c|}
\hline $\begin{array}{l}\text { SL. } \\
\text { No. }\end{array}$ & Parameter & Measured Properties \\
\hline 1 & $\begin{array}{l}\text { Particle Size } \\
\text { Analysis }\end{array}$ & $\begin{array}{l}\text { Soil Texture(gravel, sand ,silt ,clay } \\
\text { percentage), Percentage Finer }\end{array}$ \\
\hline 2 & $\begin{array}{l}\text { Consistency } \\
\text { Limits }\end{array}$ & $\begin{array}{l}\text { Liquid Limit, Plastic Limit, Shrinkage } \\
\text { Limit, Moisture Content, Dry Density, } \\
\text { Specific Gravity }\end{array}$ \\
\hline 3 & $\begin{array}{l}\text { Shear } \\
\text { Strength }\end{array}$ & Cohesion, Angle of Internal Friction, \\
\hline 4 & $\begin{array}{l}\text { Compressive } \\
\text { Strength }\end{array}$ & $\begin{array}{l}\text { Optimum Moisture Content, } \\
\text { Maximum Dry Density, Compression } \\
\text { Index, Swelling Potential }\end{array}$ \\
\hline 5 & $\begin{array}{l}\text { Flow } \\
\text { Properties }\end{array}$ & $\begin{array}{l}\text { Permeability, Void Ratio, Porosity, } \\
\text { Depth of Water Table }\end{array}$ \\
\hline
\end{tabular}

\subsection{Collection of Samples}

Seven representative towns/sites were selected on outgoing/passing National \& State highways around the Luckow covering the circumference of the Luckow City where possible growth of the city is inevitable. It was assumed that first the radial expansion along the existing road will take place. The study areas ranging from towns/village, Tehsil headquarters, to district head quarters shown in figure 1.

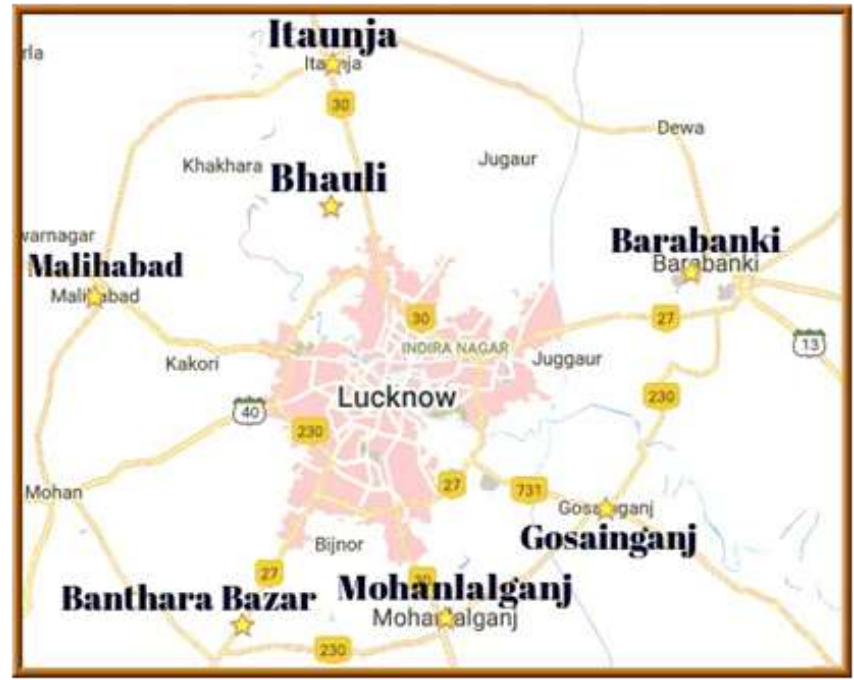

Fig -1: Map Showing The Selected Towns/ Sites

The location of the selected sites ranging from $19 \mathrm{Kms}$ to 35 Kms from Charbaag Railway Station in different directions and 4to $15 \mathrm{~km}$ from the present existing boundary of the city. All the selected sites are located either on National Highway or State Highway.

Table-2-Selected Towns Around The Lucknow City

\begin{tabular}{|c|c|c|c|}
\hline $\begin{array}{l}\text { Selected } \\
\text { Town/Location }\end{array}$ & Description & Road Link & $\begin{array}{l}\text { Distance } \\
\text { From } \\
\text { Charbaag }\end{array}$ \\
\hline Mohanlalganj & $\begin{array}{l}\text { Tehsil Headquarter } \\
\text { of Lucknow District }\end{array}$ & $\begin{array}{l}\text { Lucknow- } \\
\text { Raibareli } \\
\text { Road(SH- } \\
40)\end{array}$ & $19 \mathrm{Km}$ \\
\hline Itaunza & $\begin{array}{l}\text { Town \& Nagar } \\
\text { Panchayat in } \\
\text { Lucknow District }\end{array}$ & $\begin{array}{l}\text { Lucknow- } \\
\text { Sitapur } \\
\text { Road(NH- } \\
\text { 24) }\end{array}$ & $31 \mathrm{~km}$ \\
\hline Banthara Bazar & $\begin{array}{l}\text { Town/Village in } \\
\text { Sarojini nagar } \\
\text { Tehsil in Lucknow }\end{array}$ & $\begin{array}{l}\text { Lucknow- } \\
\text { Unnao } \\
\text { Road(NH- } \\
25)\end{array}$ & $22 \mathrm{~km}$ \\
\hline Barabanki & $\begin{array}{l}\text { District Headquarter } \\
\text { of U.P. }\end{array}$ & $\begin{array}{l}\text { Lucknow- } \\
\text { Fazabad } \\
\text { Road(NH- } \\
28)\end{array}$ & $32 \mathrm{Km}$ \\
\hline Gosaiganj & $\begin{array}{l}\text { Town \& Nagar } \\
\text { Panchayat in } \\
\text { Lucknow District }\end{array}$ & $\begin{array}{l}\text { Lucknow- } \\
\text { Sultanpur } \\
\text { Road(NH- } \\
56)\end{array}$ & $21 \mathrm{~km}$ \\
\hline Malihabad & $\begin{array}{l}\text { Town and Tehsil } \\
\text { head quarter in } \\
\text { Lucknow District }\end{array}$ & $\begin{array}{l}\text { Situated on } \\
\text { Lucknow - } \\
\text { Hardoi } \\
\text { Road(SH- } \\
25)\end{array}$ & $35 \mathrm{Km}$ \\
\hline Bhauli & $\begin{array}{l}\text { Sub location(Town } \\
\text { or Village) under } \\
\text { Bakshi Ka Talab, } \\
\text { Lucknow }\end{array}$ & $\begin{array}{l}\text { Lucknow- } \\
\text { Sitapur } \\
\text { Road(NH- } \\
\text { 24) }\end{array}$ & $20 \mathrm{Km}$ \\
\hline
\end{tabular}


Sample collection and test performance were carried out from January to April month nearly three months closing of the rainy season and before the starting of the summer season so that measured parameters are not influenced by rain water / summer heat and show the stable and true picture .However since the worst condition of the shear strength of the soil is in moist stage the direct shear test was carried out in wet condition. For the collection of soil samples $1 \mathrm{sq} \mathrm{km}$ area on both sides of the existing road for each location was undertaken for study. Samples were taken at the corner points of the square having sides of approx. 0.5 $\mathrm{km}$.

\section{EXPERIMENTAL RESULTS AND ANALYSIS}

\subsection{Experimental Observation and Analysis}

Soil samples taken from eighteen trial pits of each site/location at depths of $1 \mathrm{~m}$ and $2 \mathrm{~m}$ were used for the investigation. Both disturbed and undisturbed samples at two depths in low lying areas and six soil samples at two depths within the Lucknow city representing the whole area covered by the city to serve as control sample for comparative study. The location of the control pits are at Indiranagar, Gomtinagar, Rajabajar, Alambaag, Nishat Ganj and Medical College. The various tests/analysis required for the properties mentioned in table 1 were carried out.

\subsection{Particle Size Analysis}

Both sieve analysis and sedimentation analysis was carried out and test results are shown in table 3.

Table-3-Particle Size Analysis

\begin{tabular}{|l|l|l|l|l|l|l|}
\hline \multirow{2}{*}{ Selected Town/ Location } & \multicolumn{3}{|l|}{ SIEVE ANALYSIS } & \multicolumn{2}{l|}{ SEDIMENTATION ANALYSIS } \\
\cline { 2 - 8 } & $\mathbf{4 . 7 5} \mathbf{m m}$ & $\mathbf{2 m m}$ & $\mathbf{0 . 4 2 5} \mathbf{m m}$ & $\mathbf{0 . 0 7 5} \mathbf{m m}$ & $\mathbf{0 . 0 0 2} \mathbf{m m}$ & $<.002 \mathbf{m m}$ \\
\hline Mohanlalganj & 98 & 72 & 64 & 35 & 12 & 23 \\
\hline Itaunza & 100 & 84 & 70 & 65 & 39 & 26 \\
\hline Banthara Bazar & 100 & 95 & 84 & 73 & 56 & 17 \\
\hline Barabanki & 97 & 75 & 65 & 32 & 18 & 14 \\
\hline Gosaiganj & 100 & 83 & 78 & 68 & 46 & 22 \\
\hline Malihabad & 100 & 84 & 73 & 62 & 40 & 22 \\
\hline Bhauli & 100 & 97 & 87 & 75 & 62 & 13 \\
\hline
\end{tabular}

From the results of sieve and sedimentation analysis the percentage gravel, sand, silt and clay content for soils of each sites were determined and are shown in table 4 and figure 2 .

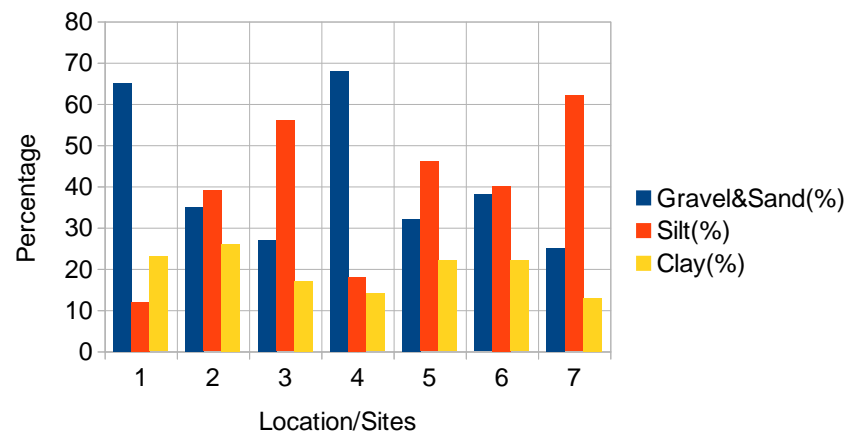

Fig 2-percentage gravel, sand, silt and clay content

Table-4 -Percentage silt, gravel ,clay content of the soil

\begin{tabular}{|l|l|l|l|l|l|l|l|}
\hline Parameter & $\begin{array}{l}\text { Mohanlal } \\
\text { ganj }\end{array}$ & Itaunza & $\begin{array}{l}\text { Banthara } \\
\text { Bazar }\end{array}$ & $\begin{array}{l}\text { Bara } \\
\text { banki }\end{array}$ & $\begin{array}{l}\text { Gosai } \\
\text { ganj }\end{array}$ & $\begin{array}{l}\text { Maliha } \\
\text { bad }\end{array}$ & Bhauli \\
\hline Percentage Finer & 35 & 65 & 73 & 32 & 68 & 62 & 75 \\
\hline Gravel\&Sand(\%) & 65 & 35 & 27 & 68 & 32 & 38 & 25 \\
\hline Silt(\%) & 12 & 39 & 56 & 18 & 46 & 40 & 62 \\
\hline Clay(\%) & 23 & 26 & 17 & 14 & 22 & 22 & 13 \\
\hline
\end{tabular}

\subsubsection{Consistency Limits Analysis}

For the identification of characteristics the tests of liquid limit, plastic limit, shrinkage limit, moisture content, and specific gravity were carried out as per Indian Standard test procedure of the collected samples and mean values of the test results are shown in table 5 
Table-5 -Consistency Limit Analysis

\begin{tabular}{|c|c|c|c|c|c|c|}
\hline Location/Town & Liquid Limit & Plastic Limit & Plasticity Index & Shrinkage Limit & Moisture content & Specific Gravity \\
\hline Mohanlalganj & 38 & 23 & 15 & 21 & 24.3 & 2.56 \\
\hline Itaunza & 42 & 30 & 12 & 28 & 25.8 & 2.68 \\
\hline Banthara Bazar & 49 & 38 & 11 & 30 & 27.4 & 2.80 \\
\hline Barabanki & 40 & 24 & 16 & 20 & 24.6 & 2.54 \\
\hline Gosaiganj & 45 & 32 & 13 & 27 & 26.2 & 2.72 \\
\hline Malihabad & 46 & 32 & 14 & 29 & 26.0 & 2.65 \\
\hline Bhauli & 52 & 42 & 10 & 32 & 27.7 & 2.76 \\
\hline
\end{tabular}

\subsubsection{Shear Strength and Compressive Strength}

\section{Analysis}

Estimation of soil shear strength and compressive strength is required for the design of foundation so that stability of slopes and soils can be assessed. This may aso be used to constitute the ability of soil to withstand stresses and strains associated with naturally occurring substances such as pore pressure, cracking, swelling, leaching and weathering. For the shear strength assessment direct shear box test was carried out on soil samples collected in moist condition since shear strength is lowest in saturated soil. The parameters determined for shear strength were cohesion and angle of internal friction whereas for compressive strength were maximum dry density, optimum moisture content, compression index and swelling potential.

Table-6 -Shear Strength and Compressive Strength Analysis

\begin{tabular}{|c|c|c|c|c|c|c|}
\hline Location/Town & Cohesion & $\begin{array}{l}\text { Angle of Internal } \\
\text { Friction }\end{array}$ & $\begin{array}{l}\text { Maximum Dry } \\
\text { Density }\end{array}$ & $\begin{array}{l}\text { Optimum Moisture } \\
\text { Content }\end{array}$ & $\begin{array}{l}\text { Compression } \\
\text { Index }\end{array}$ & $\begin{array}{l}\text { Swelling } \\
\text { Potential }\end{array}$ \\
\hline Mohanlalganj & 0.46 & 12 & 1.58 & 16.50 & 0.140 & 21.00 \\
\hline Itaunza & 0.10 & 15 & 1.80 & 22.50 & 0.148 & 25.00 \\
\hline Banthara Bazar & 0.22 & 18 & 1.72 & 18.00 & 0.142 & 23.50 \\
\hline Barabanki & 0.42 & 11 & 1.60 & 15.00 & 0.135 & 19.00 \\
\hline Gosaiganj & 0.32 & 08 & 1.65 & 19.50 & 0.146 & 22.00 \\
\hline Malihabad & 0.40 & 14 & 1.76 & 18.00 & 0.145 & 24.00 \\
\hline Bhauli & 0.12 & 16 & 1.78 & 21.00 & 0.152 & 27.50 \\
\hline
\end{tabular}

\subsubsection{Properties Relating To Flow Through Soils}

\section{Analysis}

Engineering behavior of the most types of the soils is affected by water, which plays an important role in the occurrence as well as solution of geotechnical problems. The flow of water through soil medium takes place through interconnected pores. For characterizing the soil it is very essential to be aware of the flow of water through soils to assess the properties related to the water movement of the soil and depth of water table below ground level to incorporate corrective measures during the planning and design stages for the structures to be constructed over these foundations. The test results of the measured properties i.e. Voids ratio, porosity, permeability and depth of water table below ground level for each site in this regard are shown in table 7.

Table-7- Properties Relating to flow through Soil's Analysis

\begin{tabular}{|l|l|l|l|l|}
\hline Location/Town & Void Ratio & Porosity & Permeability & Depth of Water Table \\
\hline Mohanlalganj & 0.550 & 35.00 & 0.0400 & $32 \mathrm{~m}$ \\
\hline Itaunza & 0.720 & 42.00 & 0.0450 & $8 \mathrm{~m}$ \\
\hline Banthara Bazar & 0.650 & 40.00 & 0.0440 & $15 \mathrm{~m}$ \\
\hline Barabanki & 0.580 & 37.00 & 0.0420 & $34 \mathrm{~m}$ \\
\hline Gosaiganj & 0.645 & 39.00 & 0.0430 & $20 \mathrm{~m}$ \\
\hline Malihabad & 0.670 & 40.00 & 0.0450 & $22 \mathrm{~m}$ \\
\hline Bhauli & 0.680 & 41.00 & 0.0460 & $6 \mathrm{~m}$ \\
\hline
\end{tabular}




\subsection{Comparative/Statistical Analysis}

The mean values of $r$ different parameters of each site/location along with mean value of test results obtained from soil samples collected from the six locations i.e.
Indiranagar, Gomtinagar, Rajabajar, Alambaag, Nishat Ganj and Medical College inside the city to serve as control points for comparative analysis are tabulated in table 8 .

Table-8-Summary of Geotechnical Properties

\begin{tabular}{|c|c|c|c|c|c|c|c|c|}
\hline Para meter & $\begin{array}{l}\text { Control } \\
\text { Sample }\end{array}$ & $\begin{array}{l}\text { Mohanlal } \\
\text { ganj }\end{array}$ & Itaunza & $\begin{array}{l}\text { Banthara } \\
\text { Bazar }\end{array}$ & $\begin{array}{l}\text { Bara } \\
\text { banki }\end{array}$ & $\begin{array}{l}\text { Gosai } \\
\text { ganj }\end{array}$ & Malihabad & Bhauli \\
\hline Percentage Finer & 30 & 35 & 65 & 73 & 32 & 68 & 62 & 75 \\
\hline Sand \& Gravel $(\%)$ & 72 & 65 & 35 & 27 & 68 & 32 & 38 & 25 \\
\hline $\operatorname{Silt}(\%)$ & 15 & 12 & 39 & 56 & 18 & 46 & 40 & 62 \\
\hline Clay(\%) & 13 & 23 & 26 & 17 & 14 & 22 & 22 & 13 \\
\hline Liquid Limit & 32 & 38 & 42 & 49 & 40 & 45 & 46 & 52 \\
\hline Plastic Limit & 14 & 23 & 30 & 38 & 24 & 32 & 32 & 42 \\
\hline Plasticity Index & 18 & 15 & 12 & 11 & 15 & 13 & 14 & 10 \\
\hline Shrinkage Limit & 12 & 21 & 28 & 30 & 20 & 27 & 29 & 32 \\
\hline Natural Moisture Content & 25.8 & 24.3 & 25.8 & 27.4 & 24.6 & 26.2 & 26.0 & 27.7 \\
\hline Specific Gravity & 2.65 & 2.56 & 2.68 & 2.80 & 2.54 & 2.72 & 2.65 & 2.76 \\
\hline Cohesion & 0.50 & 0.46 & 0.10 & 0.22 & 0.42 & 0.32 & 0.40 & 0.12 \\
\hline Angle of Internal Friction & 24 & 12 & 15 & 18 & 11 & 08 & 14 & 16 \\
\hline Maximum Dry Density & 1.75 & 1.58 & 1.80 & 1.72 & 1.60 & 1.65 & 1.76 & 1.78 \\
\hline Optimum Moisture Content & 15 & 16.50 & 22.50 & 18.00 & 15.00 & 19.50 & 18.00 & 21.00 \\
\hline Compression Index & 0.135 & 0.140 & 0.148 & 0.142 & 0.135 & 0.146 & 0.145 & 0.152 \\
\hline Swelling Potential & 15.00 & 21.00 & 25.00 & 23.50 & 19.00 & 22.00 & 24.00 & 27.50 \\
\hline Void Ratio & 0.340 & 0.550 & 0.720 & 0.650 & 0.580 & 0.645 & 0.670 & 0.680 \\
\hline Porosity & 25 & 35 & 42 & 40 & 37 & 39 & 40 & 41 \\
\hline Permeability & 0.035 & 0.040 & 0.045 & 0.044 & 0.042 & 0.043 & 0.045 & 0.046 \\
\hline Depth of Water Table & 40 & 32 & 08 & 15 & 34 & 20 & 22 & 06 \\
\hline
\end{tabular}

These mean values has been compared with the mean values of the control sample i.e the samples collected from the locations inside the city as percentage above/ below/ not distinguished category and average percentage variation for each site has been shown in table 9 .

Table-9- Percentage Variation in Geotechnical Properties

\begin{tabular}{|l|l|l|l|l|l|l|l|l|l|l|}
\hline Para meter & $\begin{array}{l}\text { Control } \\
\text { Sample }\end{array}$ & $\begin{array}{l}\text { Mohanlal } \\
\text { ganj }\end{array}$ & Itaunza & $\begin{array}{l}\text { Banthara } \\
\text { Bazar }\end{array}$ & $\begin{array}{l}\text { Bara } \\
\text { banki }\end{array}$ & $\begin{array}{l}\text { Gosai } \\
\text { ganj }\end{array}$ & Malihabad & Bhauli \\
\hline Percentage above the mean values of soil samples collected inside the City \\
\hline Percentage Finer & 30.00 & 16.67 & 116.67 & 143.33 & 06.67 & 126.67 & 106.67 & 150.00 \\
\hline Clay(\%) & 13.00 & 76.92 & 100.00 & 30.77 & 07.69 & 69.23 & 69.23 & 00.00 \\
\hline Liquid Limlt & 32.00 & 18.75 & 31.25 & 53.13 & 25.00 & 40.63 & 43.75 & 62.50 \\
\hline Plastic Limit & 14.00 & 64.29 & 114.29 & 171.43 & 71.43 & 128.57 & 128.57 & 200.00 \\
\hline ShrinkageLimit & 12.00 & 75.00 & 133.33 & 150.00 & 66.67 & 125.00 & 141.66 & 166.67 \\
\hline Optimum Moisture Content & 15.00 & 10.00 & 50.00 & 20.00 & 00.00 & 30.00 & 20.00 & 40.00 \\
\hline Compression Index & 0.135 & 03.70 & 09.63 & 05.19 & 00.00 & 08.15 & 07.41 & 12.59 \\
\hline
\end{tabular}




\begin{tabular}{|c|c|c|c|c|c|c|c|c|}
\hline Swelling Potential & 15.00 & 40.00 & 66.67 & 56.67 & 26.67 & 46.67 & 60.00 & 83.33 \\
\hline Void Ratio & 0.340 & 61.76 & 111.76 & 91.18 & 70.59 & 89.71 & 97.06 & 100.00 \\
\hline Porosity & 25.00 & 40.00 & 68.00 & 60.00 & 48.00 & 56.00 & 60.00 & 64.00 \\
\hline Permeability & 0.035 & 14.29 & 28.57 & 25.71 & 20.00 & 22.86 & 28.57 & 31.43 \\
\hline \multicolumn{9}{|c|}{ Percentage below the the mean values of soil samples collected inside the City } \\
\hline Sand \& Gravel $(\%)$ & 72.00 & 09.72 & 51.38 & 62.50 & 05.56 & 55.56 & 47.22 & 65.28 \\
\hline Plasticity Index & 18.00 & 16.67 & 33.33 & 38.89 & 16.67 & 27.78 & 22.22 & 44.44 \\
\hline Cohesion & 00.50 & 08.00 & 80.00 & 56.00 & 16.00 & 36.00 & 20.00 & 76.00 \\
\hline Angle of Internal Friction & 24.00 & 50.00 & 37.50 & 25.00 & 54.16 & 66.67 & 41.67 & 33.33 \\
\hline Depth of Water Table & 40.00 & 20.00 & 80.00 & 62.50 & 15.00 & 50.00 & 45.00 & 85.00 \\
\hline \multicolumn{9}{|l|}{ Not Distinguished } \\
\hline $\operatorname{Silt}(\%)$ & 15.00 & 20.00 & 160.00 & 273.33 & 20.00 & 206.67 & 166.67 & 313.33 \\
\hline Natural Moisture Content & 25.80 & 05.81 & 00.00 & 06.20 & 04.65 & 01.55 & 00.78 & 07.36 \\
\hline Specific Gravity & 02.65 & 03.40 & 01.13 & 05.66 & 04.15 & 02.64 & 00.00 & 04.15 \\
\hline Maximum Dry Density & 01.75 & 09.71 & 02.86 & 01.71 & 08.57 & 05.71 & 0.571 & 01.71 \\
\hline Average $(\%)$ & 17.81 & 5.19 & 19.48 & 27.47 & 03.18 & 23.83 & 16.60 & 29.07 \\
\hline
\end{tabular}

Out of the total Twenty parameters, it is observed that eleven parameters have values exceeding than mean value of control sample while five parameters have values less than the mean value of the control sample. The four parameters are in non-distinguished category since some some location shows higher values whereas some locations have less value than the control sample mean value. The mean value of the control sample and mean value of the parameters along with standard deviation and percentage variation are shown in table 10.

Table10. Comparative study of Parameters With Control Sample

\begin{tabular}{|l|l|l|l|l|}
\hline Parameter & $\begin{array}{l}\text { Control Sample } \\
\text { Mean Value }\end{array}$ & $\begin{array}{l}\text { Mean Value of the } \\
\text { Selected Locations }\end{array}$ & $\begin{array}{l}\text { Standard } \\
\text { Deviation }\end{array}$ & $\begin{array}{l}\text { Percentage } \\
\text { Variation }\end{array}$ \\
\hline Percentage Finer & 30.00 & 55.00 & 17.68 & 83.33 \\
\hline Clay(\%) & 13.00 & 18.75 & 04.07 & 44.23 \\
\hline Liquid Limit & 32.00 & 43.00 & 07.78 & 34.38 \\
\hline Plastic Limit & 14.00 & 29.38 & 10.87 & 109.82 \\
\hline Shrinkage Limit & 12.00 & 24.88 & 09.10 & 107.29 \\
\hline Optimum Moisture Content & 15.00 & 18.19 & 02.25 & 21.25 \\
\hline Compression Index & 0.135 & 00.14 & 0.006 & 05.83 \\
\hline Swelling Potential & 15.00 & 22.13 & 05.04 & 47.50 \\
\hline Void Ratio & 0.340 & 00.60 & 0.187 & 77.76 \\
\hline Porosity & 25.00 & 37.38 & 08.75 & 49.50 \\
\hline Permeability & 0.035 & 00.04 & 0.005 & 21.43 \\
\hline Sand \& Gravel(\%) & 72.00 & 45.25 & 18.92 & 37.15 \\
\hline Plasticity Index & 18.00 & 13.50 & 03.18 & 25.00 \\
\hline Cohesion & 00.50 & 14.75 & 00.13 & 36.50 \\
\hline Angle of Internal Friction & 24.00 & 21.13 & 06.54 & 38.54 \\
\hline Depth of Water Table & 40.00 & 15.00 & 12.64 & 44.69 \\
\hline Silt(\%) & 140.05 & 140.0 \\
\hline
\end{tabular}




\begin{tabular}{|l|l|l|l|l|}
\hline Natural Moisture Content & 25.80 & 25.98 & 00.12 & 00.68 \\
\hline Specific Gravity & 02.65 & 02.67 & 0.014 & 00.75 \\
\hline Maximum Dry Density & 01.75 & 01.71 & 0.032 & 02.57 \\
\hline Average(\%) & 17.81 & $20 . .59$ & 6.11 & 27.97 \\
\hline
\end{tabular}

\section{CONCLUSION}

For arriving at final conclusion soil site rating for each site on seven point scale based on soil properties i.e the laboratory test results and a three point scale based on the uses of soil was developed/designed and carried out as shown in table 11 .

Table-11- Soil \& Site Rating of Selected Town/ location

\begin{tabular}{|c|c|c|c|c|c|c|c|}
\hline Parameter & $\begin{array}{l}\text { Mohanlal } \\
\text { ganj }\end{array}$ & Itaunza & $\begin{array}{l}\text { Banthara } \\
\text { Bazar }\end{array}$ & $\begin{array}{l}\text { Bara } \\
\text { banki }\end{array}$ & $\begin{array}{l}\text { Gosai } \\
\text { ganj }\end{array}$ & Malihabad & Bhauli \\
\hline \multicolumn{8}{|l|}{ Based On Soil Properties } \\
\hline Particle Size Analysis & 07 & 04 & 02 & 06 & 05 & 03 & 01 \\
\hline Consistency Limits & 06 & 02 & 04 & 07 & 03 & 02 & 01 \\
\hline Shear Strength & 07 & 01 & 03 & 05 & 04 & 06 & 02 \\
\hline Compressive Strength & 06 & 02 & 05 & 07 & 03 & 04 & 01 \\
\hline Flow Properties & 07 & 01 & 04 & 07 & 03 & 05 & 02 \\
\hline \multicolumn{8}{|l|}{ Based On Uses of Soil } \\
\hline Overhead tank/Buildings & 03 & 01 & 02 & 03 & 02 & 02 & 01 \\
\hline $\begin{array}{l}\text { Absorption Capability for Septic } \\
\text { Tank }\end{array}$ & 01 & 03 & 02 & 01 & 02 & 02 & 03 \\
\hline Shallow Excavation & 01 & 03 & 02 & 01 & 02 & 02 & 03 \\
\hline Local Roads \&streets & 03 & 02 & 02 & 03 & 02 & 03 & 02 \\
\hline Sand \&gravel Availability & 03 & 02 & 02 & 03 & 02 & 02 & 01 \\
\hline Road Filling Material & 03 & 02 & 01 & 03 & 02 & 02 & 02 \\
\hline Total Score $=53$ & 47 & 23 & 29 & 46 & 30 & 33 & 19 \\
\hline
\end{tabular}

On the basis of the study the following conclusions can be drawn:

- It is observed from the above table that location Malihabad and Barabanki may be categorised as best location whereas bhauli and Itaunza are the worst locations. Banthara Bazar, Gosaiganj and Malihabad falls under moderate category.

- The development/design/planning on LucknowRaibaelli Road (SH-40) and Lucknow-Faizabad Road NH-28 need no special attention and normal design of foundation practices will be sufficient and civil structures to be constructed on these locations will not impose any extra expenditure on account of the ground suitability of foundations.

- The locations falling under moderate category need to be designed for the type of structure to be located on particular location after the detailed soil investigation and adopting/mentioning proper compaction technique /soil improvement techniques.

- For Bhauli and Itaunza i.e. Lucknow-Sitapur Road (NH-24) as the soil is not suitable for development of civil engineering structures, the foundations are not desirable until the special ground improvement technique such as mechanical stabilization, addition of admixtures(soil,lime, cement or other), themal stabilization by heating the ground at temperature more than 500 degree centrigrade, preloading, Dynamic compaction/replacement,geotextile reinforcement is adopted.

\section{REFERENCES}

[1] Annor, A.E; Olasehinde, P.I and Pal, P.C 1987. Basement fracture patterns in the control ofwater channels An example from Central Nigeria. Paper presented at the 23 rd Annual Conference of the Nigerian Mining and Geosciences Society, Benin, pp 9.

[2] British Standard Methods of Test for soils forCivil Engineering Purposes. B.S 1377: Part2, 1990. Published by the British StandardsInstitution, pp 8200.

[3] Carter M 1983 Geotechnical Engineering Handbook, Pentech Press, 226pp 
[4] Dun, T.S, Anderson L.R. and Keifer 1980Fundamental of Geotechnical Analysis John Wiley Publisher, 414 pages.

[5] Geotechnical Engineering, Pitman, 507pgs. Longman, 536 pp Merki, J.P.1970. Structural Geology of the Cenozoic Niger Delta. African Geology.University of Ibadan Press.pp251-268

[6] Murthy V.N.S 1984 Soil Mechanics and Foundation Engineering, Dhanpart Rai and Sons, India.763 pgs.

[7] NEDECO 1961 Water of the Niger, Niger Delta Environmental Survey 1999 Physical Environment Report on the Hydrology of the Niger Delta Ngah, S.A and Nwankwoala, H.O 2013.Evaluation of Geotechnical Properties of the Sub-soil for Shallow Foundation Design in Onne, Rivers State, Nigeria. The Journal of Engineering and Science, Vol. 2 11: 08 - 16

[8] Nwankwoala, H.O and Amadi, A.N 2013. Geotechnical Investigation of Sub-soil andRock Characteristics in parts of Shiroro- Muya-Chanchaga Area of Niger State, Nigeria. International Journal of Earth Sciences and Engineering, Vol.61:8 17.

[9] Oghenero, A.E; Akpokodje, E.G and Tse, A.C2014.Geotechnical Properties of Subsurface Soils in Warri, Western Niger Delta, Nigeria. Journal of Earth Sciences and Geotechnical Engineering, 41: 89102

[10] Oke, S.A and Amadi, A.N 2008. An assessment of the geotechnical properties of the sub- soil of parts of Federal University of Technology, Minna, Gidan Kwano Campus, for foundation design and construction. Journal of Science, Education and Technology, Vo.1 2:87 102

[11] Oke, S.A; Okeke, O.E; Amadi, A.N; Onoduku, U.S 2009. Geotechnical properties of the sub-soil for designing shallow foundation in some selected parts of Chanchaga area, Minna, Nigeria. Journal of Environmental Science, 11:45 54.

[12] Peck, R.B; Hanson W.E and Thornburn T.H 1973 Foundation Engineering 2 nd Edition John Wiley and Sons 514 pgs.

[13] Reyment, R.A 1965. Aspects of Geology of Nigeria. University of Ibadan Press, Nigeria. 133p

[14] Short, K.C and Stauble, A.J 1967. Outline geology of the Niger Delta. Bull. Am. Ass. Petrol Geol. 54:761 779

[15] Skempton, A.W and MacDonald D.H. 1956:The Allowable Settlement of Buildings, Proc. Inst. Of Civil Engineers, Part 3, Vol.5, pp. 727-784.

[16] Tomlinson M. J 1999 Foundation Design and Construction 6 th Edition,

[17] Vickers B 1978 Laboratory Work in Soil Mechanics, Second Edition Nwankwoala, H.O and Warmate, T 2014.Geotechnical Assessment of Foundation Conditions of a Site in Ubima, Ikwerre Local Government Area, Rivers State, Nigeria. International
Journal of Engineering Research and Development IJERD 98: 5063.

[18] Youdeowei, P.O and Nwankwoala, H.O 2013.Suitability of soils as bearing media at afresh water swamp terrain in the Niger Delta. Journal of Geology and Mining Research, Vol.53: 58 - 64

\section{BIOGRAPHIES}

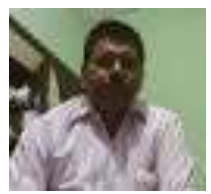

Ajai Kumar Rai received the B.E. and M. Tech. degrees in Civil Engineering from Madan Mohan Malviya Engineering College, Gorakhpur, India (NowMMMUT) in 1982 and KNIT, Sultanpur, India in 2014 respectively. At present working as Assistant Professor, Department of Civil Engineering, Sri Ram Swaroop Memorial College of Engineering \& Management, Lucknow, Uttar Pradesh, India.

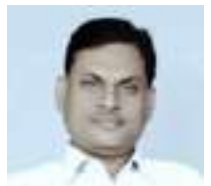

Brajesh Mishra received the B.E. and M. Tech. degrees in Civil Engineering from Madan Mohan Malviya Engineering College, Gorakhpur, India (NowMMMUT) in 1988 and KNIT, Sultanpur, India in 2014 respectively. At present working with U.P. Cane Development Department, Lucknow, responsible for construction of road projects. 